\title{
Serum hormonal levels in HIV/AIDS infected male subjects on antiretroviral therapy (ART) in Nnewi, Nigeria
}

\author{
I.P. EZEUGWUNNE ${ }^{1}$, C.C. ONYENEKWE ${ }^{2}$, J.E. AHANEKU ${ }^{2}$, \\ M. IFEANYICHUKWU ${ }^{3 *}$, S.C. MELUDU ${ }^{1}$, O.W. ONWURAH ${ }^{4}$, F.N. OSUJI ${ }^{5}$ \\ ${ }^{I}$ Department of Human Biochemistry; College of Health Sciences, Nnamdi Azikiwe University, Nnewi, Nigeria. \\ ${ }^{2}$ Department of Chemical Pathology; College of Health Sciences, Nnamdi Azikiwe University, Nnewi, Nigeria. \\ ${ }^{3}$ Department of Immunology, College of Health Sciences, Nnamdi Azikiwe University, Nnewi, Nigeria. \\ ${ }^{4}$ Heamatology Department; Nnamdi Azikiwe University Teaching Hospital, Nnewi, Nigeria. \\ ${ }^{5}$ Immaculate Heart Hospital and Maternity. P.O. Box 29 Nkpor, Anambra State, Nigeria. \\ *Corresponding author, E-mail: goodnessifeoma007@yahoo.com
}

\begin{abstract}
This study was designed to assess the serum hormonal levels (Follicle Stimulating Hormone (FSH), Luteinizing Hormone (LH), Testosterone, Estrogen, Progesterone, Prolactin and Cortisol) in symptomatic HIV/AIDS male subjects on ART. A total of 411 participants aged between 17 and 58 (43 \pm 10$)$ years were randomly recruited for the study. The participants were staged and grouped as follows: symptomatic HIV/AIDS male subjects on ART $(n=139)$, symptomatic HIV/AIDS male subjects not on ART $(n=136)$ and HIV seronegative subjects $(n=136)$. Blood samples were collected from the participants for the determination of HIV status by immunochromatography and HIV confirmation by Western Blot. Enzyme Linked Immunosorbent assay (ELISA) was used to assay for FSH, LH, Testosterone, Estrogen, Progesterone, Prolactin and Cortisol levels. Their results showed significant rise in FSH, LH in HIV seropositive participants on ART compared respectively to those not on ART and the HIV seropositive subjects ( $\mathrm{p}<0.05)$. On the other hand, the Estrogen, Progesterone, Prolactin and Cortisol were all raised in symptomatic HIV seropositive participants not on ART compared respectively to the symptomatic HIV seroposive on ART and the HIV seronegative groups $(\mathrm{p}<0.05)$. The testosterone levels significantly decreased in both symptomatic HIV infected subjects on ART and those not on ART compared with the HIV seronegative controls $(\mathrm{p}<0.05)$. The relevance of HIV infection on the serum hormonal status is that HIV infection causes hypogonadism as well as primary testicular failure in symptomatic HIV participants not on ART. Also, HIV infection causes hyperprolactinaemia, hyperprogesteronaemia and hypercortisolism in symptomatic HIV participants not on ART.

(C) 2012 International Formulae Group. All rights reserved.
\end{abstract}

Keywords: HIV, ART, participants, ELISA, symptomatic, hormonal levels.

\section{INTRODUCTION}

A number of disease conditions have been reported to affect endocrine organs. The infiltration of endocrine glands by tumor or infections has been observed (WHO, 2006). Endocrine manifestations of Human
Immunodeficiency Virus (HIV) infection has been reported to include both pathological changes and disturbances in function. The endocrine manifestations may be as a result of direct effect of the HIV infection on glands.Such glands affected by HIV infection 
include the liver (Houssat et al., 1990), adrenal (Pransanthai et al., 2007; Meena et al., 2011) and gonads (Roof and Hall, 2000). Cardiovascular disorders have also been implicated in HIV infection (Sarivastava et al., 2004), especially in advanced stage of the infection (Cohen et al., 2005)

HIV is transmitted via exposure to contaminated body fluids, such as blood (Baggaley et al., 2006) or breast milk (Salazar-Gonzalez et al., 2011). Possible routes of transmission include blood transfusions (Dwyre et al., 2011), intravenous drug use (Raguin et al., 2011) and unprotected sexual intercourse (Hariri and Mekenna, 2007).

As HIV continues to survive and replicate within its human host, it eventually weakens the immune system; this leaves the infected individual susceptible to opportunistic infections and neoplasms which have been observed to have affected the endocrine system in patients with AIDS (Onyancha and Ocholla, 2009). Also, patients treated with long-term antiretroviral therapy usually develop lipodystrophy, insulin resistance, and increased cardiovascular risk. Regrettably, these drug-induced conditions diminish patients' quality of life and contribute to an increased rate of cardiovascular events and diabetes (Palios et al., 2011).

Most HIV-infected persons have been reported to have elevated basal Cortisol levels (Corcoran and Grinspoon, 1999). Meena et al., (2011) demonstrated a high incidence of endocrine dysfunction in HIV infected patient. They also observed high incidence of gonadal dysfunction in those subjects. Low Testosterone levels with elevated LH and FSH have also been documented in patients with symptomatic or advanced HIV disease, thereby suggesting primary testicular failure in this grouu8p (Villette et al., 1990). Leserman (2008) has revealed that depression, stressful events and trauma might affect HIV disease progression and Cortisol being a stressful hormone might be increased in HIV disease.

However, since most of the findings on the effect of HIV on the endocrine system documented were not observed in Nigeria, hence, the design of this study was to assess the effect of HIV infection in some endocrine hormones in symptomatic HIV infected subjects on ART in Nigeria to see if there will be differences in the results.

\section{MATERIALS AND METHODS Subjects}

A total of 411 male participants aged between 17 and $68(43 \pm 10)$ years were randomly recruited at both Antiretroviral Therapy (ART) Clinic and Voluntary Counseling and Testing (VCT) Centre in Nnamdi Azikiwe University Teaching Hospital (NAUTH), Nnewi, Nigeria. Based on World Health Organisation (WHO) criteria for HIV staging, the participants were staged and grouped as follows: symptomatic HIV stage 11 subjects on ART $(\mathrm{N}=139)$. Lamivudine, $150 \mathrm{mg}$ twice daily, Stavudine, 40mg twice daily and Nevirapine, $200 \mathrm{mg}$ twice daily: this was administered to the symptomatic HIV stage 11 subjects on ART. Symptomatic HIV subjects not on ART $(n=136)$ and HIV seronegative subjects $(n=136)$. The subjects were given informed consent, while the study design was approved by the ethical committee of Nnamdi Azikiwe University Teaching Hospital, Nnewi, Nigeria. $5 \mathrm{ml}$ of blood sample were collected from each of the participant in the groups. The participants were screened for HIV infection using Immunoassay and Immunochromatographic method. The serum was used for the estimation of FSH, LH, Testosterone, Estrogen, Progesterone, Prolactin and Cortisol levels. The serum samples were stored at -20 ${ }^{\circ} \mathrm{C}$ until analyzed.

\section{Detection of antibodies to HIV-1 and HIV-2 in human plasma \\ Two different methods were used, namely, Abbott determine TM HIV -1 and}


HIV-2 kit, which is an in-vitro visually read immunoassay (Abbott Japan Co.Ltd.Tokyo, Japan) and HIV-1 and 2 STAT-PAK Assay kit, which is an Immunochromatographic test for the quantitative detection of antibodies to HIV-1 and HIV-2 in Human plasma (CHEMBIO Diagnostic system, Inc, New York, USA). For the Abbott determine TM HIV -1 and HIV-2 kit, the procedure described by the manufacturer were used for the analysis. Briefly, $50 \mu \mathrm{l}$ of participant serum samples separated from the corresponding whole blood samples in EDTA were applied to the appropriately labeled sample pad. After 15 minutes but not more than 60 minutes of sample application, the result was read. This method has inherent quality control that validates the results. For the Immunochromatographic method for HIV -1 and HIV-2, the procedure described by the manufacturer was used for the analysis. In brief, $5 \mathrm{ml}$ of participant's plasma were dispensed into the sample well in the appropriately labeled sample pad. Three drops of the buffer supplied by the manufacturer were added into the appropriately labeled sample pad. The results of the test were read at 10 minutes after the addition of the running buffer. This method has inherent quality control and validates the results.

$\mathrm{CD}^{+} \mathrm{T}$ CELL Count by Flow Cytometry $200 \mathrm{ml}$ EDTA whole blood was collected into PARTEC test tubes (Rohren tube). Then $20 \mu \mathrm{l} \mathrm{ofCD} 4^{+} \mathrm{T}$ antibodies were added into the tube. The contents were mixed and incubated in the dark for 15 minutes at roomtemperature. $800 \mathrm{ml}$ of CD4 buffer were gently added into the mixture and mixed gently. Then, the Partec tube was plugged on the Cyflow counter and the $\mathrm{CD} 4^{+} \mathrm{T}$ cells were displayed as peaks and interpreted as figures.

\section{Estimation of FSH by Randox Laboratories Limited, U.K}

Serum FSH was estimated by Enzyme Linked Immunosorbent assay (ELISA). The procedure were as described by the manufacturer of the kit (Randox Laboratories
Limited, UK): $50 \mu \mathrm{l}$ of serum sample were added to appropriately labeled microtitre wells and $100 \mu \mathrm{l}$ Enzyme conjugated detection antibody were also added to the wells. The same procedures were performed for the standard as well as HIV negative control serum samples. They were incubated at room temperature for 45 minutes. The wells were washed 3 times with deionized water to remove unbound antibodies. $100 \mu \mathrm{l}$ tetramethylbenzidine (TMB) reagent were added and well incubated at room temperature for 20 minutes for the colour to develop. $100 \mu 1$ of hydrochloric acid (HCL) were added to the various wells to stop further development of colour. Absorbance was read at $450 \mathrm{~nm}$ using ELISA machine and deionized water served as blank. The test and control samples concentrations were extrapolated from the standard curve. The standard curve was plotted from the absorbance values and concentrations of series of FSH standards $(0,5,15,50,100$ and 200 $\mathrm{miu} / \mathrm{ml}$ ) provided by the manufacturer of the kit.

\section{Estimation of LH by Randox Laboratories Limited, U.K}

Serum LH was estimated by Enzyme Linked Immunosorbent assay (ELISA). The procedure was as described by the manufacturer of the kit (Randox Laboratories Limited, UK): $50 \mu \mathrm{l}$ of serum sample were added to appropriately labeled microtitre wells and $100 \mu \mathrm{l}$ Enzyme conjugated detection antibody were also added to the wells. The same procedure was performed for the standard as well as HIV negative control serum samples. They were incubated at room temperature for 45 minutes. The wells were washed 3 times with deionized water to remove unbound antibodies. $100 \mu \mathrm{l}$ TMB reagents were added and well incubated in the dark for 20 minutes for the colour to develop. $100 \mu 1$ of HCL were added to the various wells to stop further development of colour. Absorbance was read at $450 \mathrm{~nm}$ using ELISA machine and deionized water served as blank. 
The test and control samples concentrations were extrapolated from the standard curve. The standard curve was plotted from the absorbance values and concentrations of series of FSH standards $(0,5,15,50,100$ and 200 $\mathrm{miu} / \mathrm{ml}$ ) provided by the manufacturer of the kit.

\section{Estimation of Testosterone by Randox Laboratories Limited, U.K}

Serum Testosterone was estimated by Enzyme Linked Immunosorbent assay (ELISA). The procedure was as described by the manufacturer of the kit (Randox Laboratories Limited, UK): $10 \mu \mathrm{l}$ of serum sample were added to appropriately labeled microtitre wells and $100 \mu \mathrm{l}$ Enzyme conjugated detection antibody were also added to the wells. Also, $5 \mu 1$ of rabbit antiTestosterone reagent were added in each well. The same procedure was performed for the standard as well as HIV negative control serum samples. They were incubated at $37{ }^{\circ} \mathrm{C}$ for 90 minutes. The wells were washed 3 times with deionized water to remove unbound antibodies. $100 \mu \mathrm{l}$ TMB reagent were added and well incubated at room temperature for 20 minutes for the colour to develop. $100 \mu \mathrm{l}$ of HCL were added to the various wells to stop further development of colour. Absorbance was read at $450 \mathrm{~nm}$ using ELISA machine and deionized water served as blank. The test and control samples concentrations were extrapolated from the standard curve. The standard curve was plotted from the absorbance values and concentrations of series of FSH standards $(0$, $0.1,0.5,2,6$ and $18 \mathrm{ng} / \mathrm{ml}$ ) provided by the manufacturer of the kit.

\section{Estimation of Estradiol by Randox Laboratories Limited, U.K}

Serum Estradiol was estimated by Enzyme Linked Immunosorbent assay (ELISA). The procedure was as described by the manufacturer of the kit (Randox Laboratories Limited, UK): $25 \mu \mathrm{l}$ of serum sample were added to appropriately labeled microtitre wells and $100 \mu \mathrm{l}$ Enzyme conjugated detection antibody were also added to the wells. Also, $5 \mu \mathrm{l}$ of rabbit antiEstradiol reagent were added in each well. The same procedure was performed for the standard as well as HIV negative control serum samples. They were incubated at $37{ }^{\circ} \mathrm{C}$ for 90 minutes. The wells were washed 3 times with deionized water to remove unbound antibodies. $100 \mu \mathrm{l}$ TMB reagent were added and well incubated at room temperature for 20 minutes for the colour to develop. $100 \mu \mathrm{l}$ of HCL were added to the various wells to stop further development of colour. Absorbance was read at 450nm using ELISA machine and deionized water served as blank. The test and control samples concentrations were extrapolated from the standard curve. The standard curve was plotted from the absorbance values and concentrations of series of FSH standards ( 0 , $10,30,100$ and $1000 \mathrm{pg} / \mathrm{ml}$ ) provided by the manufacturer of the kit.

\section{Estimation of Progesterone by Randox Laboratories Limited, U.K}

Serum Progesterone was estimated by Enzyme Linked Immunosorbent assay (ELISA). The procedure was as described by the manufacturer of the kit (Randox Laboratories Limited, UK); $25 \mu 1$ of serum sample were added to appropriately labeled microtitre wells and $100 \mu \mathrm{l}$ Progesterone Enzyme horseradish peroxidase conjugate reagent were added to the wells. Also, $50 \mu 1$ of rabbit anti-Progesterone reagent was added in each well. The same procedure was performed for the standard as well as HIV negative control serum samples. They were incubated at room temperature for 90 minutes. The wells were washed 3 times with deionized water to remove unbound antibodies. $100 \mu \mathrm{l}$ TMB reagent were added and well incubated at room temperature for 20 minutes for the colour to develop. $100 \mu \mathrm{l}$ of HCL was added to the various wells to stop further development of colour. Absorbance were read at $450 \mathrm{~nm}$ using ELISA machine and 
deionized water served as blank. The test and control samples concentrations were extrapolated from the standard curve. The standard curve was plotted from the absorbance values and concentrations of series of FSH standards $(0,0.5,3,10,25$ and 50 $\mathrm{ng} / \mathrm{ml}$ ) provided by the manufacturer of the kit.

\section{Estimation of Prolactin by Randox Laboratories Limited, U.K}

Serum Prolactin was estimated by Enzyme Linked Immunosorbent assay (ELISA). The procedure was as described by the manufacturer of the kit (Randox Laboratories Limited, UK); $50 \mu \mathrm{l}$ of serum sample were added to appropriately labeled microtitre wells and $100 \mu 1$ Enzyme conjugate reagent were also added to the wells. The same procedure was performed for the standard as well as HIV negative control serum samples. They were incubated at room temperature for 45 minutes. The wells were washed 3 times with deionized water to removed unbound antibodies. $100 \mu \mathrm{l}$ TMB reagents were added and well incubated at room temperature for 20 minutes for the colour to develop. $100 \mu \mathrm{l}$ of HCL were added to the various wells to stop further development of colour. Absorbance was read at $450 \mathrm{~nm}$ using ELISA machine and deionized water served as blank. The test and control samples concentrations were extrapolated from the standard curve. The standard curve was plotted from the absorbance values and concentrations of series of FSH standards (0, 5, 15, 50, 100 and 200 $\mathrm{ng} / \mathrm{ml}$ ) provided by the manufacturer of the kit.

\section{Estimation of Cortisol byRandox Laboratories Limited, U.K}

Serum Cortisol was estimated by Enzyme Linked Immunosorbent assay (ELISA). The procedure were as described by the manufacturer of the kit (Randox Laboratories Limited, UK): $20 \mu \mathrm{l}$ of serum sample were added to appropriately labeled microtitre wells and $200 \mu$ l Enzyme conjugate reagent were also added to the wells. The same procedure was performed for the standard as well as HIV negative control serum samples. They were incubated at room temperature for 60 minutes. The wells were washed 3 times with deionized water to remove unbound antibodies. $100 \mu \mathrm{l}$ TMB reagent were added and well incubated at room temperature for 20 minutes for the colour to develop. $100 \mu \mathrm{l}$ of HCL were added to the various wells to stop further development of colour. Absorbance was read at $450 \mathrm{~nm}$ using ELISA machine and deionized water served as blank. The test and control samples concentrations were extrapolated from the standard curve. The standard curve was plotted from the absorbance values and concentrations of series of FSH standards (0, 20, 50, 100, 200, 400 and $800 \mathrm{ng} / \mathrm{ml}$ ) provided by the manufacturer of the kit.

\section{Statistical analysis}

The result of the analysis was statistically analysed. Students't-test and one way analysis of variance (ANOVA) were used to compare means. The analysis was performed with the use of Statistical Package for Social Sciences (SPSS) statistical software package, version 13.0. P $\quad<0.05$ was considered statistically significant.

\section{RESULTS}

The result of analysis of variance showed that the serum levels of FSH, LH, Testosterone, Estrogen, Progesterone, Prolactin and Cortisol were significantly different amongst the group $(\mathrm{F}=15.56,10.40$, $38.40, \quad 11.34, \quad 27.77,23.22$ and 59.96) $(\mathrm{p}<0.05)$ respectively.

The result of independent student's ttest showed that serum FSH $(\mathrm{miu} / \mathrm{ml})$ level was significantly higher in HIV seropositive participants on ART 15.21 ( \pm 7.70$)$ compared with HIV seropositive participants not on ART $12.63( \pm 8.57)(\mathrm{p}<0.05)$. Also, the serum FSH level in HIV seropositive participants on 
ART HIV seropositive participants on ART was significantly higher than the value in HIV seronegative participants $10.03 \quad( \pm 6.67)$ $(p<0.05)$. Similarly, the serum FSH value in HIV seropositive participants not on ART $12.63( \pm 8.57)$ was significantly higher than the value in HIV seronegative participants $10.03( \pm 6.67)(\mathrm{p}<0.05)$.

The result of independent student's ttest showed that serum $\mathrm{LH}(\mathrm{miu} / \mathrm{ml})$ level was significantly higher in HIV seropositive participants on ART $13.38( \pm 7.19)$ compared with HIV seropositive participants not on ART $11.16( \pm 7.70)(\mathrm{p}<0.05)$. Similarly, the serum LH level in HIV seropositive participants on ART HIV 13.38( \pm 7.19$)$ was significantly higher than the value in HIV seronegative participants $9.44 \quad( \pm 6.61)$ $(\mathrm{p}<0.05)$. Also, the serum LH value in HIV seropositive participants not on ART 11.16 $( \pm 7.70)$ was significantly higher than the value in HIV seronegative participants $9.44( \pm 6.61)$ $(\mathrm{p}<0.05)$.

The mean $( \pm \mathrm{SD})$ of serum Testosterone (ng/ml) levels in HIV seropositive participants on ART $2.68 \quad( \pm 2.04)$ was significantly lower compared with the corresponding value in HIV seronegative participants $4.74( \pm 1.83)(\mathrm{p}<0.05)$. Again, the mean $( \pm \mathrm{SD})$ of serum Testosterone value was significantly lower in HIV seropositive participants not on ART $2.91 \quad( \pm 6.21)$ compared with the value in HIV seronegative participants $4.74( \pm 1.83)(\mathrm{p}<0.05)$. However, no significant mean differences was observed between HIV seropsitive participants with and without ART $(\mathrm{p}<0.05)$.

The mean $( \pm \mathrm{SD})$ of serum Estrogen (pg/ml) level in HIV seropositive participants on ART $55.12( \pm 36.89)$ showed significantly higher value compared with HIV seronegative group $32.81 \quad( \pm 20.92) \quad(\mathrm{p}<0.05)$. Also, the mean $( \pm \mathrm{SD})$ Estrogen $(\mathrm{pg} / \mathrm{ml})$ value observed in HIV seropositive participants not on ART $60.73( \pm 22.72)$ was significantly higher compared with the value in HIV seronegative group $32.81( \pm 20.92)(\mathrm{p}<0.05)$. However, the mean $( \pm \mathrm{SD})$ Estrogen $(\mathrm{pg} / \mathrm{ml})$ showed similar values in HIV seropositive participants on ART $55.12( \pm 36.89)$ and in HIV seropositive participants not on ART $60.73 \quad( \pm 22.72)$ $(\mathrm{p}<0.05)$.

The mean $( \pm \mathrm{SD})$ of serum Progesterone (ng/ml) level was significantly lower in HIV seropositive participants on ART $1.93( \pm 1.54)$ compared with the value in HIV seropositive participants not on ART $2.34 \quad( \pm 1.51)$ $(\mathrm{p}<0.05)$. Also, the mean $( \pm \mathrm{SD})$ of serum Progesterone $(\mathrm{ng} / \mathrm{ml})$ level was significantly higher in HIV seropositive participants on ART $1.93( \pm 1.54)$ compared with the value in HIV seronegative group $1.11 \quad( \pm 1.06)$ $(\mathrm{p}<0.05)$.

The mean $( \pm \mathrm{SD})$ of serum Prolactin (ng/ml) level was significantly lower in HIV seropositive participants on ART $6.63( \pm 4.36)$ compared with the value in HIV seropositive participants not on ART $9.83 \quad( \pm 4.32)$ $(\mathrm{p}<0.05)$. Similarly, significantly lower in mean $( \pm \mathrm{SD})$ Prolactin $(\mathrm{ng} / \mathrm{ml})$ value was observed in HIV seropositive participants on ART $6.63( \pm 4.36)$ compared with HIV seronegative group $8.93 \quad( \pm 3.31) \quad(\mathrm{p}<0.05)$. However, no significant mean difference in serum Prolactin (ng/ml) was observed in HIV seropositive participants not on ART 9.83 ( \pm 4.32$)$ compared with HIV seronegative group $8.93( \pm 3.31)(\mathrm{p}<0.05)$.

The mean $( \pm \mathrm{SD})$ of serum Cortisol (ng/ml) level was significantly lower in HIV seropositive participants on ART 127.98 $( \pm 69.90)$ compared with the value in HIV seropositive participants not on ART 238.63 $( \pm 129.12)(\mathrm{p}<0.05)$. Also, the mean $( \pm \mathrm{SD})$ of serum Cortisol (ng/ml) level was significantly higher in HIV seropositive participants not on ART $238.63( \pm 129.12)$ compared with HIV seronegative group $138.86( \pm 64.28)(\mathrm{p}<0.05)$. However, no significant mean difference in serum Cortisol (ng/ml) was observed in HIV seropositive participants on ART 127.98 ( \pm 69.90$)$ compared with HIV seronegative group $138.86( \pm 64.28)(\mathrm{p}<0.05)($ Table 1$)$. 
Table 1: Mean $( \pm \mathrm{SD})$ serum hormonal levels in male symptomatic HIV/AIDS participants on ART, not on ART and HIV seronegative control group.

\begin{tabular}{|c|c|c|c|c|c|c|c|}
\hline Variables & $\begin{array}{c}\text { FSH } \\
(\mathrm{miu} / \mathrm{ml})\end{array}$ & $\begin{array}{c}\text { LH } \\
(\mathrm{miu} / \mathrm{ml})\end{array}$ & $\begin{array}{c}\text { Testosterone } \\
(\mathrm{miu} / \mathrm{ml})\end{array}$ & $\begin{array}{l}\text { Estrogen } \\
(\mathrm{miu} / \mathrm{ml})\end{array}$ & $\begin{array}{c}\text { Progesterone } \\
(\mathrm{ng} / \mathrm{ml})\end{array}$ & $\begin{array}{c}\text { Prolactin } \\
(\mathrm{ng} / \mathrm{ml})\end{array}$ & $\begin{array}{c}\text { Cortisol } \\
\text { (ng/ml) }\end{array}$ \\
\hline Symptomatic HIV/AIDS on ART (n=139) & $15.21 \pm 7.70$ & $13.38 \pm 7.19$ & $2.68 \pm 2.04$ & $55.12 \pm 3.89$ & $1.93 \pm 1.54$ & $6.63 \pm 4.36$ & $127.98 \pm 69.90$ \\
\hline Symptomatic HIV/AIDS not on ART $(n=139)$ & $12.62 \pm 8.57$ & $11.16 \pm 7.70$ & $2.91 \pm 6.21$ & $60.73 \pm 22.72$ & $2.34 \pm 1.51$ & $9.83 \pm 4.32$ & $238.63 \pm 129.12$ \\
\hline HIV Seronegative Control $(\mathrm{n}=136)$ & $10.03 \pm 6.67$ & $9.44 \pm 6.61$ & $4.74 \pm 1.83$ & $32.83 \pm 20.92$ & $1.11 \pm 1.06$ & $8.93 \pm 3.31$ & $138.86 \pm 64.28$ \\
\hline \multirow[t]{2}{*}{ FP } & 15.56 & 10.4 & 38.4 & 11.34 & 27.77 & 23.22 & 59.96 \\
\hline & $<0.05$ & $>0.05$ & $>0.05$ & $>0.05$ & $>0.05$ & $<0.05$ & $<0.05$ \\
\hline $\mathrm{TI}^{\mathrm{a}}$ & $<0.05$ & $<0.05$ & $>0.05$ & $>0.05$ & $<0.05$ & $<0.05$ & $<0.05$ \\
\hline $\mathrm{TIp}^{\mathrm{b}}$ & $<0.05$ & $<0.05$ & $<0.05$ & $<0.05$ & $<0.05$ & $<0.05$ & $>0.05$ \\
\hline $\operatorname{TIp}^{c}$ & $<0.05$ & $<0.05$ & $<0.05$ & $<0.05$ & $<0.05$ & $>0.05$ & $<0.05$ \\
\hline
\end{tabular}

Fp = HIV on ART subjects, HIV not on ART subjects and HIV seronegative control group compared using ANOVA;

TIp $^{\mathrm{a}}=$ HIV on ART subjects compared with HIV not on ART subjects (using student's t-test);

$\operatorname{TIp}^{\mathrm{b}}=$ HIV on ART subjects compared with HIV seronegativecontrol subjects (using student's t-test);

$\operatorname{TIp}^{c}=$ HIV not on ART subjects compared with HIV seronegativecontrol subjects (using student's t-test). 


\section{DISCUSSION}

The study revealed a significant higher mean values in serum FSH and LH levels in symptomatic HIV seropositive participants on ART than in the HIV seropositive participants. The implication of this finding could be that HIV infection has a stimulatory effect on the release of these hormones from the pituitary. Also, the implication of elevated serum FSH and LH levels in symptomatic HIV seropositive participants signify that the HIV infection has a hypogonadal effect on the testicles. This finding is in the support of the report that elevated serum FSH and LH levels have been implicated in HIV infection with hypogonadism (Purohit et al., 2004; Selimeryer and Grunfeld, 2006).

In this study, the serum Testosterone level was significantly lower in symptomatic HIV participants. Also, the serum Estrogen value was significantly higher in symptomatic HIV participants. This implies that the HIV infection might have interfere with the gonadal Tesotosterone synthesis or it has favors the formation of Estrogen from Testosterone which also known as Estrogenic effect hence the low serum Testosterone observed in these subjects. Estrogenic effect is a peripheral conversion of Testosterone to Estrogen by Aromatase and Enolase (Meinhardt and Mullis, 2002).

Nevertheless, low Testosterone has been implicated in hypogonadism in asymptomatic HIV infection (Roof and Hall, 2000) Low serum Testosterone levels with elevated LH and FSH levels have also been reported in patients with symptomatic or advanced HIV disease, indicating primary testicular failure (Meena et al., 2011).

The serum Prolactin level was also observed to be elevated in symptomatic HIV participants not on ART. The observed increase in Prolactin value might be as a result of the disease burden on the pituitary, thereby causing an increased stimulation and secretion of Prolactin into the circulation. Hyperprolactinaemia has been linked to impotence and loss of libido (Gregg et al.,
1997). Also, hyperprolactinaemia has been linked with gynaecomasia in HIV subjects (Biglia et al., 2004). The reduced Prolactin level observed on those on drug might be as a result of health recovery from ART treatment (Burgoyne and Tan, 2008; Dybul et al., 2002).

This study also observed that the serum Progesterone and Cortisol level were significantly high in symptomatic HIV participants. These values were significantly higher in symptomatic HIV participants not on ART. The implication might be that the HIV infection retards the synthesis of Progesterone. Cortisol is synthesized from Progesterone through glucocorticoid pathway (John et al., 2007). So, the elevated serum Cortisol observed in symptomatic HIV participants not on ART might be as a result of stress impact from the HIV infection. Other researchers have reported hypercortisolism in HIV infected subjects as a result of stress impact from the disease (Leserman, 2008; Meena et al., 2011). Also, Cortisol as stress steroid hormone is released in response to stress or anxiety (Gropper et al., 2008). Indeed, Unachukwu et al. (2009) observed that it was virtually every endocrine organ is involved in the course of HIV infection just as was seen in this study.

\section{Conclusion}

The present study thus concludes that HIV infection causes hypogonadism as well as primary testicular failure in symptomatic HIV participants not on ART as evidenced by the elevated levels of serum FSH, LH and low Testosterone. Also, HIV infection causes hyperprolactinaemia, hyperprogesteronaemia and hypercortisolism in symptomatic HIV participants not on ART. Hence, this study suggests that HIV infection causes endocrine abnormalities especially the gonads and the adrenal glands.

\section{REFERENCES}

Baggaley R Boily C, White R, Alary M. 2006. Risk of HIV-1 transmission for parenteral exposure and blood transfusion: a 
systematic review and meta-analysis. AIDS, 20(6): 805-812.

Biglia A, Blanco J, Martínez E, Domingo P, Casamitjana R, Sambeat M, Milinkovic A, Garcia M, Laguno $M$, Leon A, Larrousse M, Lonca M, Mallolas J, Gatell J. 2004. Gynecomastia among HIVinfected patients is associated with hypogonadism: a case-control study. Clin. Infect. Dis., 39(10): 1514-1519.

Burgoyne R, Tan D. 2008. Prolongation and quality of life for HIV-infected adults treated with high active antiretroviral therapy (HAART): a balancing act. $J$. Antimicrob. Chemother., 61(3): 469-473.

Cohen C, Karstaedt A, Frean J, Thomas J, Govender N, Prentice E, Dini L, Galpin J, Crewe-Brown H. 2005. Increased prevalence of severe malaria in HIVinfected adults in South Africa. Clin. Infect. Dis., 41: 1631-1637.

Corcoran C, GrinspoonS. 1999. Treatments for wasting in patients with the acquired immunodeficiency syndrome diagnosis and treatment of endocrine disorders in the HIV-infected patient. New England Journal of Medicine, 340(22): 1740-1750.

Dybul M, Fauci A, Bartlett J, Kaplan J, Pau A. 2002. Panel on Clinical Practices for Treatment of HIV. Guidelines for using antiretroviral agents among HIV-infected adults and adolescents. Ann. Intern. Med., 137: 381-433.

Dwyre D, Fernando L, Holland P. 2011. Hepatitis B, Hepatitis C and HIV Transfusion-Transmitted Infections in the $21^{\text {st }}$ Century. Vox Sang, 100(1): 92-98.

Gregg C, Shikar V, Larsen P, Mak G, Chojnacki A, Yong V, Weiss S. 2007. White matter plasticity and enhanced remyelination in the maternal CNS. J. Neurosci., 27(8): 1812-1823.

Gropper SS, Smith JL, Groff JL. 2008. Advanced Nutrition and Human Metabolism. National Academies Press: Washington, DC; 247.
Hariri S, Me Kenna M. 2007. Epidemiology of Human immunodeficiency virus in the United States. Clin. Mocrobiol. Rev., 20: 474-488.

Housset C, Boucer O, Girard PM, Leibowtch J, Saimot AJ, Brechot C, Marche C. 1990. Immunohistochemical evidence for human Immunodeficiency virus-1 infection of liver kupfer cells. Human Pathology, 21(4): 404-408.

John S, Sorokin A, Thompson P. 2007. Phytosterols and vascular disease. Curr. Opin. Lipidol., 18(1): 35-40.

Leserman J. 2008. Role of depression, stress and trauma in HIV disease progression. Psychosomatic Medicine, 70: 539-545.

Meinhardt U, Mullis P. 2002. The essential role of the aromatase/p450arom. Semin. Reprod. Med, 20(3): 277-284.

Onyancha O, Ocholla D. 2009. Is HIV/AIDS in Africa Distinct? What Can We Learn From an Analysis of the Literature? Scientometrics, 79(1): 277-296.

Palios J, Kadoglou P, Lampropoulos S. 2011. The Pathophysiology of HIV-/HAARTRelated Metabolic Syndrome Leading to Cardiovascular Disorders: The Emerging Role of Adipokines. Exp. Diabetes Res., 2012: 103063.

Prasanthai V, Sunthornyothin S, Phothongkum P, Suankratay C. 2007. Prevalence of adrenal insufficiency in critically ill patients with AIDS. J. Med. Assoc. Thai., 90: 1768-1774.

PurohitS, Wu D, Shinohara K, Turek P. 2004. A prospective comparison of 3 diagnostic methods to evaluate ejaculatory duct obstruction. $J$. Urol., 171(1): 232-236.

Raguin G, Lepretre A, Ba I, Ndoyes I, Toufika A, Brucker G, Girard P. 2011. Drug Use and HIV in West Africa: a Neglected Epidemic. Trop. Med. Health, 16(9): 1131-1133.

Roof R, Hall E. 2000. Gender differences in acute CNS trauma and stroke: neuroprotective effects of estrogen and 
progesterone. J. Neurotrauma., 17(5): 367-388.

Salazar-Gonzalez J, Salazar M, Learn G, Fouda G, Kang H, Mahlokozera T, Wilks A, Lovingood R, Stacey A, Kalilani L, Meshnick S, Borrow P, Montefiori D, Denny T, Letvin N, Shaw G, Hahn B, Permar S. 2011. Origin and Evolution of HIV-1 in Breast Milk Determined by Single-Genome Amplification and Sequencing. J. Virol., 85(6): 2751-2763.

Selimeyer E, Grunfeld C. 2006. Endocrine and metabolic disturbances in human immunodeficiency virus infection and syndrome. Endocr. Rev., 17: 518-532.

Srivastava M, Verghese C, Sepkowitz D. 2004. Acute Reversible Heart failure with Antiretroviral. Ther. Apy. Am. J. Therapy., 11(4): 323-325.

Unachukwu CN, Uchenna DI, Young EE. 2009. Endocrine and metabolic disorders associated with human immune deficiency virus infection. West Afr. J. Med., 28(1): 3-9.

Villette J, Bourin P, Doinel C, Mansour I, Fiet J, Boudou P, Dreux C, Roue R, Debord M, Levi F. 1990. Circadian variations in plasma levels of hypophyseal, adrenocortical and testicular hormones in men infected with human immunodeficiency virus. J. Clin. Endocrinol. Metab., 70: 572-577.

WHO. 2006. WHO case definitions of HIV for surveillance and revised clinical staging and immunological classification of HIV-related disease in adults and children. WHO. 